\title{
Bilgi Paylaşma Davranışının Planlı Davranış Teorisi ve Sosyal Değişim Teorisi Bağlamında İncelenmesi: Dermatologlar Üzerine Ampirik Bir Araştırma
}

\author{
An Examination of Knowledge Sharing Behavior in the Context of the Theory of Planned \\ Behavior and Social Exchange Theory: An Empirical Investigation on Dermatologists
}

Aysun ÇETIN' ${ }^{1}$, Melike ŞENTÜRK²

\section{ÖZET}

Mesleklerin ve daha genel anlamda bilimin gelişim hızını belirleyen en önemli etmenlerden birisi, meslek dallarında yer alan bireylerin birbirleri arasında profesyonel bilgiyi etkin bir şekilde paylaşmasından geçmektedir. Ancak, bilgiye sahip olan bireylerin çeşitli nedenlerden dolayı bilgiyi paylaşmak yerine saklama eğiliminde oldukları da bilinmektedir. Bu nedenle, birey seviyesinde bilgi paylaşma davranışını olumlu ve olumsuz olarak etkileyen çeşitli faktörlerin incelenmesine yönelik çalışmalar tüm insanlık için önem arz etmektedir. $\mathrm{Bu}$ motivasyonla gerçekleştirilen araştırmada, teorik çerçeve olarak Planlı Davranış Teorisi ve Sosyal Değişim Teorisi benimsenmiş ve bu teorilerden hareketle bireylerin bilgi paylaşma davranışını etkilediği düşünülen faktörler olarak "kişisel çıktı beklentisi", "bilgi gücü kaybı beklentisi", "karşılık beklentisi" ve "bilgi paylaşımına yönelik tutum" arasındaki ilişkiler incelenmiştir. Araştırma hipotezlerini test etmek için, bilgi paylaşımının hayati öneme sahip olduğu hekimlik mesleğini icra eden bireylerden Türkiye genelindeki 254 dermatologdan elde edilen verilerle nicel bir araştırma yürütülmüştür. Araştırmanın sonuçlarına göre, dermatologların kişisel çıktı ve karşılık beklentilerinin bilgi paylaşımına yönelik tutumlarını olumlu olarak; bilgi gücü kaybı beklentilerinin ise, olumsuz olarak etkilediği tespit edilmiştir. Ayrıca, bilgi paylaşımına yönelik tutumun da bilgi paylaşma davranışını olumlu olarak etkilediği gözlemlenmiştir. Araştırmanın sonuçları, araştırma modelini doğrulamış ve dermatologların bilgi paylaşma davranışlarını tahmin etmede Planlı Davranış Teorisi ve Sosyal Değişim Teorisinin açıklayıcı etkisini ortaya koymuştur.

Anahtar Kelimeler: Bilgi Paylaşma Davranışı, Kişisel Çıktı Beklentisi, Bilgi Gücü Kaybı Beklentisi, Karşılık Beklentisi, Planlı Davranış Teorisi, Sosyal Değişim Teorisi

\begin{abstract}
One of the most important factors that determine the growth pace of professions, and of science in the wider sense, takes places through the effective sharing of the professional knowledge by the individuals from various fields of profession. However, it is also known that those individuals who possess knowledge are inclined to hide it, instead of sharing it, due to various reasons. Therefore, the studies devoted to the examination of the factors affecting the knowledge sharing behavior at the individual level positively or negatively are vital to the humanity. In the study carried out by this motivation, the Theory of Planned Behavior and Social Exchange Theory were appropriated as the theoretical frameworks, and based on these, the relationships among "expectation of personal output", "expectation of loss of knowledge power", "expectation of reciprocity", and "attitude towards knowledge sharing" were examined as the factors considered to be affecting the knowledge sharing behavior of individuals. In order to test the research hypotheses, a quantitative investigation was carried out based on the data obtained from physicians from 254 dermatologists across Turkey, among whom the knowledge sharing is of vital importance. Taking the research results into consideration, it has been seen that personal output and reciprocity expectations of dermatologists affect their attitudes towards knowledge sharing positively, whereas their expectations concerning the loss of knowledge power affect their attitudes towards knowledge sharing negatively. Moreover, it has also been observed that the attitude towards knowledge sharing affects the knowledge sharing behavior positively. The results of the study has confirmed the research model and has demonstrated the explanatory powers of the Theory of Planned Behavior and Social Exchange Theory in estimating dermatologists' behavior of knowledge sharing.
\end{abstract}

Keywords: Knowledge Sharing Behavior, Personel Output Expectations, Loss of Knowledge Power, Reciprocity Expectation, Theory of Planned Behavior, Social Exchange Theory 


\section{GiRiş}

Bir meslek dalındaki insanlar arasında bilgi paylaşımı ne kadar artarsa, mesleğe ait ortak bilgi birikimi ve dolaylı olarak insanlığın yaşam kalitesi de o kadar artacaktır. Özellikle hekimlik gibi tüm insanlık için büyük önem arz eden ve aynı zamanda bilgi yoğun bir meslekte sahip olunan bilginin paylaşımı daha da önemli olmaktadır. Bilgi paylaşımı, günümüzde bilgi yönetimi alanındaki en önemli odak noktalarından birisidir; çünkü, bilginin ait olduğu bilim dalındaki gelişimin önündeki en önemli engellerden biri, bireylerin bilgi paylaşma davranışı sergileme konusundaki isteksizlikleridir (Hendriks, 1999: 91). Nonaka ve Konno (1998)'ya göre bilgi, bireylere yani onu yaratan, tanıyan, arşivleyen, ulaşan ve görevlerini yürütmede uygulayan çalışanlara aittir. Bilginin bireysel ve örgütsel sınırlar boyunca hareket etmesi ve örgütsel uygulamalarda kullanılması çalışanların bilgi paylaşma davranışlarıyla mümkün olmaktadır. Bir başka ifadeyle, bilgi ticari bir mal gibi serbestçe dolaşabilecek bir yapıya sahip olmadığı için, dolaşımı ona sahip olan özneye bağımlıdır (Hendriks, 1999:92). Üstelik, bireyler bilgilerini paylaşmaya istekli olsalar bile, bilginin \% 80'ini oluşturan örtük bilgiler, kaynağın "kulakları arasında ve gözlerinin arkasında" yerleşik olduğu için kolay kolay başkalarına aktarılamamaktadır (O'Dell vd., 2003:130-131).

Dolayısıyla, bireysel ve örgütsel anlamda bilgi paylaşımını artırmak ve iyileştirmek için yapılan çok yüksek maliyetli yatırımlara rağmen bilgi paylaşımı konusunda beklenen seviyelere ulaşılamamaktadır. 1997'de Ernst \& Young tarafından 431 Amerikalı ve Avrupalı örgüt ile gerçekleştirilen bir çalışmada, bilgi yönetimi konusundaki en büyük zorluğun "bireyin bilgi paylaşma davranışını değiştirmek" olduğu ifade edilmektedir (Rugless, 1998'den aktaran Bock ve Kim, 2002:14). Nitekim Bartol ve Srivastava (2002:64) da bireylerin bilginin hareketliliğini sağlayan ana etmenler olduğunu belirtmişlerdir. Bilgiye sahip olan kişilerin çeşitli bireysel karakteristiklerinin "bilgi paylaşma davranışı" üzerindeki etkisi çok büyüktür (Wang ve Noe, 2010:116).

Bilgi paylaşma davranışını "Sosyal Değişim Teorisi" çerçevesinde inceleyen çeşitli teorik ve ampirik çalışmalarda (Constant vd., 1994; Szulanski, 1996; Quinn vd., 1996; Wasko ve Faraj, 2000; Hall, 2001; Bock ve Kim, 2002; Husted ve Michailova, 2002; Bock vd., 2005; Wasko ve Faraj, 2005; Chennamaneni, 2006) bilgi gücü kaybı beklentisi, kişisel çıktı beklentileri, karşılık beklentileri, öz-yeterlilik algısı, sosyal sermaye, güven, algılananörgütsel destek, algılanan iş arkadaşı desteği, örgütsel iklim ve motivasyon gibi pek çok faktörün bilgi paylaşımına yönelik tutum ve davranış üzerinde etkisi araştırılmıştır. Bilgi paylaşma davranışı "Planlı Davranış Teorisi" kapsamında değerlendirildiğinde de bilgi paylaşımına yönelik tutumun bilgi paylaşma davranışını etkilediği gözlemlenmektedir (Bock ve Kim, 2002; Chennamaneni, 2006).

Bilgi paylaşma davranışı ile ilgili sınırlı sayıda çalışmanın yer aldığı Türkçe literatürdeki önemli çalışmalardan biri, örgütlerde bilgi paylaşma davranışını sosyal sermaye boyutları açısından ele almıştır. Araştırmanın sonuçlarına göre, sosyal sermaye boyutları ve içsel kontrolün örgütlerde örtülü bilgiyi paylaşım davranışını olumlu yönde etkilediği; buna karşın dışsal kontrolün etkilemediği bulunmuştur (Göksel vd., 2011). Yine aynı yazarların bir başka çalışmalarında ise, sosyal sermayenin ve içsel denetim odaklılığın örtülü bilgi paylaşım niyetini arttırdığı ve bireylerin örtülü bilgi paylaşım niyetlerinin, örtülü bilgiyi paylaşma davranışına dönüştüğü gösterilmiştir (Aydıntan vd., 2010). Yeniçeri ve Demirel (2007) tarafından tekstil sektörü çalışanları üzerine yapılan bir çalışmada, örgütlerde bilgi paylaşımına yönelik bireysel ve örgütsel engeller ele alınmış ve otoriter yönetim biçimin örgütsel düzeyde bilgi paylaşımını engellediği ve örgütsel engeller arttıkça bireysel engellerin de artacağı ifade edilmiştir. Benzer şekilde Köseoğlu vd. (2009) de örgütlerde bilgi paylaşımını en çok etkileyen faktörün örgütsel faktörler olduğu ve bunu daha sonra sırası ile bireysel ve teknolojik faktörlerin takip ettiğini bulgulamışlardır. Demirel ve Seçkin (2008), örgütlerde bilgi paylaşımının yenilikçiliğe etkisini ortaya koyarken; Zaim vd. (2012) de örtülü bilgi ile hem kurumsal hem de bireysel performans arasında doğrusal bir ilişki olduğunu belirtmişlerdir.

Dolayısıyla bütün bu açıklamalardan, Türkçe literatürde bilgi paylaşma davranışının daha çok örgütsel düzeyde ele alındığı veya paylaşımın örgütsel yararlarına odaklanıldığı; birey seviyesindeki bilgi paylaşımına yönelik çalışmaların ise yetersiz kaldığı görülmektedir. Buradan hareketle, hekimler arasındaki bilgi paylaşma davranışını destekleyen ya da engelleyen bireysel faktörler incelenmesi gereken değerli bir konu olarak karşımıza çıkmaktadır. Bilgi paylaşımına yönelik araştırmaların büyük bir bölümü sosyal değişim üzerinden yürüdügü halde, sosyal değişim ile bilgi paylaşımı arasındaki ilişkiyi bilgi sağlayıcı birey bakış açısı ile inceleyen çalışmaların 
sayısı kısıtlıdır. Literatürdeki bu önemli boşluk gözlemlenerek gerçekleştirilen çalışmada, birey seviyesindeki bilgi paylaşma davranışını olumlu ve olumsuz olarak etkileyen faktörler planlı davranış teorisi ve sosyal değişim teorisi bağlamında ele alınmıştır.

\section{KURAMSAL ÇERÇEVE}

\subsection{Bilgi Paylaşma Davranışı}

Bilgi, son derece anlamlı, olumlu, umut dolu ve tam olarak anlaşılması güç kavramlardan biridir (von Krogh, Ichijo ve Nonaka, 2002:16). Bilgi konusunda kayda geçmiş ilk çalışmalar en azından Platon ve Aristo'ya kadar uzanmakla birlikte, modern çağda Michael Polanyi, Ikujiro Nonaka, Daniel Bell, Peter Drucker ve Alvin Toffler gibi düşünce adamlarının araştırmalarıyla öne çıkmıştır (O'Dell vd., 2003). Nonaka (1994:15), bilgiyi "gerekçelendirilmiş gerçek inanış" olarak tanımlamış, kişinin kendi inançlarının doğruluğunu dünyaya ilişkin gözlemlerine dayanarak gerekçelendirdiğini ve bu nedenle bilginin kişiye özgü bakış açısına, duyarlılık düzeyine ve deneyimlere dayandığını ifade etmiştir. Bu tanım çerçevesinde bilgi, soyut, statik ve evrensel bir kavram olmaktan çok; bireylerin inançlarını gerekçelendirdiği dinamik bir süreç olarak kabul edilmektedir. Polanyi (1966:4), bilginin temelde açık bilgi (explicit) ve örtük bilgi (tacit) olmak üzere iki biçimde var olduğunu; açık bilginin, kitaplar, belgeler, raporlar ve veri tabanlarında yer alan bilgilerken; örtük bilginin, çalışanların beyninde ve deneyimlerinde yer alan bilgiler olduğunu ifade etmektedir (akt.: Nonaka, 1994). Bilginin örtüklüğü, bilginin açıkça ifade edilebilme ve düzenlenebilme zorluğunun derecesini göstermektedir (Swift ve Virick, 2013). Açık bilgi sözlü iletişimle paylaşılabilirken, örtülü bilgi ise sosyalleşme, gözlem ve çıraklık gibi yollar ile paylaşılmaktadır (Bartol ve Srivastava; 2002).

Bilginin genel tanımı bu şekilde yapılabilmekle beraber işletmelerde bilgi paylaşımı konusu kapsamında bilgi, "işe ilişkin bilgiler ve görevleri yürütebilmek için gerekli uzmanlık" olarak tanımlanmaktadır (Kubo vd., 2001: 467). Bilgi paylaşımı ise, bireyin, diğer kişilere yardım etmek ya da onlarla problemleri çözmek, yeni fikirler geliştirmek, prosedürleri uygulamak vb. konularda işbirliği yapabilmek adına sahip olduğu her türlü bilgi birikimini bu kişilere tedarik etmesi anlamına gelmektedir (Cummings, 2004: 352). Bu noktada, bilgi paylaşımını, bilgi transferi ve bilgi değişimi kavramlarından da ayrıştırmak gerekmektedir. Bilgi transferi, "örgütsel bilginin örgüt birimleri arasındaki hareketini" ifade etmektedir (Szulanski (1996: 28). Bilgi değişimi ise bireyler arası bilgi paylaşımını ifade etmekle birlikte iyi yönlü bir paylaşım anlamına gelmekte ve bir tarafın bilgi paylaşımı ile birlikte bilgi edinimini de içermektedir (Wang ve Noe, 2010: 117). Bu makale çerçevesinde bu ayrım yapılmakla beraber literatürde bilgi paylaşımı ile bilgi transferi ve bilgi değişimi kavramlarını eş anlamlı kullanan çalışmalar da mevcuttur (örn. De Vries vd., 2006; Yi, 2009).

Bilgi paylaşma davranışı, göreve ilişkin bilgi, knowhow veya bir ürün ya da sürece ilişkin geri bildirimin verilmesi ya da alınması anlamına gelmekte ve görevle ilgili sözel iletişimi, somut olguların direkt ya da endirekt değişimini, uzmanlığın koordinasyonunu ve hatta kimin hangi bilgiye sahip olduğunun bilgisini bünyesinde barındırabilmektedir (Hansen, 1999; Bartol ve Srivastava, 2002). Bilgi paylaşma davranışı, bir örgüt üyesinin bilgi birikimini örgütteki diğer üyelere yayması şeklinde meydana gelen davranış olarak da ifade edilmektedir (Hsu vd., 2007). Bu davranışlar bireylere ya da örgüte yönelik olabildiği gibi; çalışanların resmi iş yükümlülüklerinin bir parçası da olabilmektedir. Özellikle örtük bilgiler paylaşması daha zor ve sosyal etkileşim gerektiren türde bilgiler olduğu için (Yi, 2009: 68), daha fazla zaman ve çaba harcamayı gerektirmektedir.

Bu makale kapsamında, bilgi paylaşma davranışı, yalnızca bilgi kaynaklarından edinilebilinecek açık bilgileri değil; bunlara ek olarak bireye özgü deneyimleri, becerileri ve uzmanlığı da kapsayan örtük bilgileri de içermektedir. Ancak, bireyin bilgi paylaşımı basit bir konu değildir. Bilgi paylaşma davranışı insana özgü olduğundan bu davranışı anlamanın yolu, insanı anlamaktan geçmektedir. Bu noktada, bilgi paylaşma davranışının davranış boyutunun anlaşılmasında Planlı Davranış Teorisi ve Sosyal Değişim Teorisi önemli yararlar sunmaktadır.

\subsection{Planlı Davranış Teorisi}

Planlı davranış teorisi, Ajzen ve Fishbein tarafından 1970'lerde ortaya konan Sebepli Eylem Teorisi (Theory of Reasoned Action)'nin genişletilmiş halidir (Azjen, 1991:181). Sebepli Eylem Teorisi, insanların mantıklı bir biçimde davranacağını, herhangi bir eylemde bulunurken ellerinde mevcut bulunan bilgiyi dikkate alacaklarını ve söz konusu eylemin sonuçlarını değerlendireceklerini iddia etmektedir (Azjen, 1985: 12). Teori, bir kişinin bir davranışı gerçekleştirmesinin o davranışı gerçekleştirme niyetine bağlı olduğunu 
ve söz konusu niyetin de kişinin o davranışa yönelik tutumunun ve öznel normunun bir fonksiyonu olduğunu ifade etmektedir. Tutumlar ve öznel normlar kişinin bir davranışını sergileme niyetini şekillendirmekte ve bu niyet de kişinin arzulanan davranışı gerçekleştirip gerçekleştirmeyeceğini belirlemektedir (Fishbein ve Ajzen,1975:10-17).

Planlı Davranış Teorisinde ise, tutum ve öznel norma ek olarak "algılanan davranış kontrolü" modele eklenmiştir. Algılanan davranış kontrolü insanların söz konusu davranışı sergileme kolaylığına (ya da zorluğuna) yönelik algısıdır. Bu teoriye göre birey tutum ve öznel normları ile bir davranışı sergilemeye motive olsa da bir takım örgütsel şartlar araya girebilmekte, kişiyi davranışı yapmamaya sevk edebilmekte ve davranışa yönelik niyeti etkileyebilmektedir (Azjen, 1991). Planlı Davranış Teorisi Azjen tarafından bir şema ile şu şekilde ifade edilmiştir:

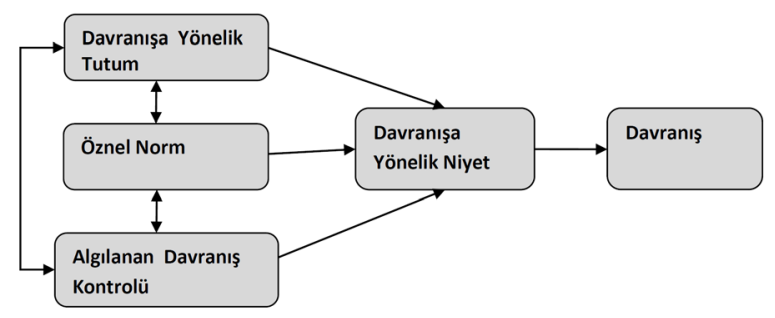

Şekil 1: Planlı Davranış Teorisi (Ajzen, 1991: 182)

Tutum ve davranış arasındaki direkt ilişki ise, çeşitli araştırmacılar tarafından inceleme altına alınmış ve tutum, davranışı etkileyen etmenlerden biri olarak belirlenmiştir (Azjen ve Fishbein, 1977: 888). Tutumlar bireyin dünyasındaki birtakım oluşumlar (örn. Diğer insanlar, kurallar, fiziksel objeler, vs.) doğrultusunda gelişir, bireyin söz konusu oluşumlara dair değerlendirmesini yansıtır (889). Bu tutumların ilgili davranışı tahmin edebilme çabaları ise "tutarlıık" kavramına dayanmaktadır. Bir davranışa karşı olumlu tutumlara sahip olan bireyin bu davranışı gerçekleştirme yönünde karar vereceği, tersi şekilde davranışa karşı olumsuz tutumları olan bireyin ise davranışı gerçekleştirmeme yönünde karar vereceği düşünülmektedir. Sonuç olarak, belirli bir davranışa yönelik tutum ile söz konusu davranış arasında bir bağdaşma olduğu varsayımı altında belirli oluşumlar bireyin bir davranışa karşı tutum geliştirmesine yol açmakta, bu tutumlarda bireyin söz konusu davranışı gerçekleştirme ya da gerçekleştirmeme kararını etkilemektedir (Azjen, 1991). Bentler ve Speckart
(1979: 452) da planlı davranış teorisini ele aldıkları ampirik çalışmalarında tutumların davranışları istatistiki olarak önemli derecede etkilediklerini belirlemiş, hatta daha da ileri giderek tutum-davranış ilişkisinde söz konusu davranışa yönelik niyetin aracı bir rol üstlenmediğini de iddia etmişlerdir.

$\mathrm{Bu}$ çalışmada da, tutumların davranışlar üzerinde direkt etkili olduğu varsayımı yapılarak "bilgi paylaşma davranışı" konusunda tutumların davranışları etkileyip etkilemediği inceleme altına alınmıştır.

\subsection{Sosyal Değişim Teorisi}

Blau tarafından 1960 'lı yıllarda geliştirilen Sosyal Değişim Teorisi (Social Exchange Theory), sosyal değişimlerdeki insan davranışını açıklamak için ortaya atılmıştır. Sosyal değişim teorisi, "karşııık normu"na vurgu yaparak sosyal değişimlerde bir kişiye karşı olumlu bir davranış sergilendiğinde, bu kişi için karşılığında belirlenmemiş bir olumlu davranış gösterme yükümlülüğü doğduğunu söylemektedir (Swift ve Virick, 2013: 718). Dolayısıyla, insanlar sosyal değişimlerde bulunurken genelde belirsiz bir gelecek getiri beklentisi içerisindedirler.

Foa ve Foa (1980), sevgi, statü, bilgi, para, mal ve hizmet olmak üzere altı değişim kaynağı belirlemiş ve bunları sınıflandırmıştır (akt.; Cropanzano ve Mitchell, 2005:880). Bu sınıflandırma çerçevesinde daha genel ve somut olan para, mal ve hizmet kaynaklarının ekonomik değişimlerde rol oynaması beklenirken; kişilere özgü ve soyut olan sevgi, statü ve bilgi kaynaklarının daha ziyade sosyal değişimlerde rol oynaması beklenmektedir. Ayrıca Ekonomik Değişim Teorisi dışsal yararları gözetirken; Sosyal Değişim Teorisinde genelde içsel yararlar incelemeye alınmaktadır (Bock ve Kim, 2002:15). Sosyal değişim teorisine göre insanların birbirleri arasındaki sosyal değişimlerde de tıpkı ekonomik değişimlerde olduğu gibi değişime ait birtakım kaynaklar, kazançlar ve maliyetler söz konusu olmaktadır (Cropanzano ve Mitchell, 2005: 880).

Bu noktada makalenin temasını oluşturan "bilgi paylaşma davranışı"nın sosyal değişimin en belirgin örneklerinden biri olduğunu gözlemlemek mümkündür. Bilgi paylaşma davranışında sosyal değişime tabi öğe, bireyin sahip olduğu "bilgi"dir. Bireyin bir başkası ile sahip olduğu bilgiyi paylaşmasında birtakım getiri ve maliyetler de devreye girmektedir. Her şeyden önce kişinin bu 
paylaşımı gerçekleştirme için önemli ölçüde emek ve zaman harcaması gerekebilmektedir (Szulanski, 1996: 31; Husted ve Michailova, 2002: 66). Buna ek olarak söz konusu bilginin paylaşımı ile kişinin bu bilgiyi, bilen tek kişi olarak sahip olduğu kendine özel gücü kaybetmesi de söz konusu olacaktır (Kankanhalli vd, 2005: 116). Bu olumsuzluklar kişinin bilgi paylaşımı konusunda gönülsüz olmasına neden olabilecektir. Dolayısıyla kişiyi söz konusu bilgi paylaşma davranışını gerçekleştirmeye yöneltecek birtakım getiriler olması da gerekmektedir (Bartol ve Srivastava, 2002: 65). Nitekim birey gerçekleştirdiği bilgi paylaşımı ile mesleki çevresindeki tanınırlı̆ını ve itibarını artırabilir, arkadaşlık bağlarını güçlendirebilir ya da mesleğinin gelişmesine sağladığı katkının hazzını yaşayabilir (Constant vd, 1994: 406; Hall, 2001: 7-11; Kankanhalli vd, 2005: 116).

Dolayısıyla, teoriye göre insanlar faydaları attıkça ve maliyetleri azaldıkça değişime yönelik olumlu bir tutum benimseyeceklerdir (Kankanhalli vd, 2005). Bock vd. (2005:91-2), ancak beklenen getirilerin algılanan maliyetleri aşması durumunda bireylerin bilgi paylaşma davranışını gerçekleştireceğine vurgu yaparak, bilgi paylaşımı gibi belirsiz sosyal çıktılara sahip bir değişim söz konusu olduğunda "sosyal değişim ilişkisi"nin davranışa yönelik tutumun en önemli belirleyicisi olduğunu da eklemişlerdir.

\subsection{Araştırmanın Çerçevesi ve Hipotezler}

Genel olarak bir bireyin davranışını, özel olarak da bilgi paylaşma davranışını ve bu davranışa yönelik tutumunu etkileyen faktörler o kadar çok sayıda ve çeşitlidir ki hepsini tek bir çalışma altında toplamak imkânsız görünmektedir. Bilgi paylaşma davranışını ele alan çalışmaların her birinde hem davranışı hem de bu davranışa yönelik tutumu etkileyen farklı farklı faktörlerin ele alındığı gözlemlenmektedir. Bu makale kapsamında, bireylerin bir sosyal değişim şeklinde gelişen "bilgi paylaşma davranışlarını" ve "bilgi paylaşımına yönelik tutumlarını" etkileyen faktörler olarak bilgi gücü kaybı beklentisi, kişisel çıktı beklentileri ve karşılık beklentilerinin etkisi incelenmiştir.

\subsubsection{Kişisel Çıktı Beklentileri ve Bilgi Paylaşımına Yönelik Tutum}

Çıktı beklentileri, bir bireyin herhangi bir davranışı sergilemesinin ya da bir görevi tamamlamasının yol açacağına inandığı olası sonuçlardır (Chui vd., 2006:1877). Bilgi paylaşımı kapsamında "kişisel çıktı beklentileri" ise, bir bilgi sağlayıcının bilgi paylaşma davranışının kendine sağlayacağı yararlara dair beklentisidir. Kişisel çıktı beklentileri aynı zamanda bireyin bir davranışına ilişkin olarak gerçekleşmesini arzuladığı fiziksel, sosyal veya ya bireysel yararlar olarak da tanımlanabilmektedir (Hsu vd., 2007:156). Nitekim önceki çalışmalar da diğer meslektaşlarının problemlerini çözen bireylerin statü ve tanınmışlıklarının arttığını göstermiştir (Lakhani ve Von Hippel, 2003:926).

Hsu vd. (2007: 156), itibar artışı, başarı, arkadaş edinme, vb. kazanımları içeren kişisel çıktı beklentilerinin bilgi paylaşma davranışı üzerindeki etkisini incelemiş ve iki değişken arasında pozitif yönlü anlamlı bir ilişki tespit etmişlerdir. Benzer bir çalışma Kankanhalli vd. (2005:120-1) tarafından gerçekleştirilmiş ve bilgi paylaşımı ile belirli kişisel çıktı beklentileri arasında pozitif bir ilişki tespit edilmiştir. Wasko ve Faraj (2000:161), özelikle bilgi kişiye ait olarak değerlendirildiğinde bilgi paylaşımına yönelik olumlu tutumların kişisel çıkar ve kazançlarla ilişkili olduğunu söylemiştir. Constant vd. (1994:4056) ise, özellikle bilgiyi değişimi yapılabilecek bir maldan ziyade kendilerinin bir parçası olarak gören bireylerin özsaygılarını ve tanınmışlıklarını artırması nedeniyle bilgi paylaşımına yönelik olumlu bir tutum geliştirdiklerini ifade etmişlerdir. Wasko ve Faraj (2005:39) ise, sosyal değişim teorisinden yola çıkarak "itibar kazanma"nın bilgi paylaşımına yönelik olumlu bir tutum geliştirmede önemli olduğunu dile getirmişlerdir. Literatürdeki pek çok çalışmada benzer faktörlere vurgu yapılarak, kişileri bilgi paylaşmaya motive eden nedenler arasında kariyerde elde edilen gelişmeler, artan tanınırlık, kişisel tatmin vb. ekonomik olmayan kişisel nedenler sıralanmıştır (Hall, 2001; Kwok ve Gao, 2004). Dolayısıyla incelenen literatürden yola çıkarak aşağıdaki hipotez geliştirilmiştir.

$H_{i}$ : Bireylerin kişisel çıktı beklentileri bilgi paylaşımına yönelik tutumlarını pozitif olarak etkilemektedir (Model: BPYT $=\beta 0+\beta 1 K C ̧ B$ ).

\subsubsection{Bilgi Gücü Kaybı Beklentisi ve Bilgi Paylaşımına Yönelik Tutum}

Husted ve Michailova (2002:65), bir bireyin mesleki anlamdaki değerinin ve gücünün sahip olduğu bilginin kalitesi ve değeri ile ilgili olduğunu söylemişlerdir. Ayrıca söz konusu sahip olunan bilgi çoğunlukla çeşitli zorluklar sonucunda elde edilmektedir. Bu nedenle de birey bilgi birikimi 
üzerinde güçlü bir kişisel iyelik hissedebilmekte ve onu saklama yönünde davranış sergileyebilmektedir. Ek olarak bazı durumlarda bilgiye tek başına sahip olmaktan ileri gelen birtakım ödüller ve başarılar elde edilebilmekte, bu da bireyin bilgi paylaşma davranışını sergilemesininönündeengeloluşturmaktadır. Bireyler arasındaki bilgi paylaşımının önündeki engellerden biri olarak, bilgisini paylaşan bireyin söz konusu bilgiye sahip olmaktan kaynaklanan üstünlüğünü kaybetme ve yeri doldurulamazlık özelliğini yok olacağı korkusu gösterilmiştir (Szulanski, 1996; Gray, 2001; Kankanhalli vd., 2005; Chennamaneni, 2006). Özelikle uzmanlık anlamında bilginin bir güç kaynağı olarak tanımlandığı ve açığa vurulmasının bireyin mesleki gücünü erozyona uğratacağı söylenmektedir (Bartol ve Srivastava, 2002; Wasko ve Faraj, 2005). Yine Quinn vd. (1996:75) de, bir meslek dalındaki insanlar arası rekabetin bilgi paylaşma davranışını baskılayabileceğini ifade etmişlerdir. Benzer şekilde, Wasko ve Faraj (2005:38) bilgi paylaşımı ile bilgi paylaşan kişi hariç herkesin yarar gördüğüne dikkati çekerek bu durumun da bilgi gücü kaybı beklentisi ile bilgi paylaşımına yönelik tutum arasındaki negatif bir ilişkinin doğmasına neden olabildiğini söylemişlerdir. Nitekim bilgi gücü kaybı beklentisi ile bilgi paylaşma davranışına yönelik tutum arasında negatif bir ilişkinin varlığını doğrulayan ampirik çalışmalar da bulunmaktadır (Chennamaneni, 2006:89). Sonuç olarak, ilgili literatür doğrultusunda aşağıdaki hipotez oluşturulmuş̧tur.

$H_{2}$ : Bireylerin bilgi gücü kaybı beklentileri bilgi paylaşımına yönelik tutumlarını negatif olarak etkilemektedir (BPYT $=\beta 0+\beta 1 B G K B)$.

\subsubsection{Karşılık Beklentisi ve Bilgi Paylaşımına Yönelik Tutum}

Hall (2001:7), bilgi paylaşımına yönelik olumlu bir tutum geliştirilmesinin kaynakları arasında diğer kişilerin bilgi birikimine erişebilme imkânını da saymıştır. Cohen (1998:31)'in "karşısındaki ile değerli bilgisini paylaşan birey karşıı̆ı̆ında başka değerli bilgiler elde etmek ister" görüşünden yola çıkan Hall (2001), bilgi paylaşma ağının bir parçası olabilmenin gerekliliklerinden birinin bilgi paylaşımına karşı olumlu bir tutum geliştirmek olduğunu ifade etmiştir. Yine, Kwok ve Gao (2004: 98) da karşılığında aynı paylaşımı görecek olma beklentisinin bireyin bilgi paylaşımına yönelik olarak olumlu bir tutum benimsemesine yol açabileceğini düşünmektedir. Bunu doğrular şekilde birçok araştırmacı da güven ve gelecekteki karşılık beklentisinin sosyal değişimlerde kilit bir rol üstlendiğini belirtmektedir (Wasko ve Faraj, 2005:43). Bock ve Kim (2002:18), yaptıkları araştırma sonucunda bireylerin karşılarındaki kişiden karşılı̆ında bilgi edinecek olmalarının bilgi paylaşımına yönelik olarak olumlu bir tutum sergilemelerine neden olduğunu tespit etmişlerdir. Yine, Bock vd. (2005:100) de karşılık beklentisi ne kadar büyük olursa, bilgi paylaşımına yönelik tutumun da o denli olumlu olacağını söylemektedirler. Ayrıca, Kankanhalli vd. (2005:122)'nin yaptıkları çalışmanın sonuçları, bilgi paylaşımına yönelik olumlu bir tutumun geliştirilmesinde karşlık beklentisinin belirgin bir rolü olabileceğini göstermiştir. Chennamaneni (2006:88)'nin ampirik araştırması da bireyin karşılık beklentisinin bilgi paylaşımına yönelik tutumunu olumlu etkilediğini doğrulamıştır. Sonuç olarak, ilgili literatür doğrultusunda aşağıdaki hipotez oluşturulmuştur.

$H_{3}$ : Bireylerin karşılık beklentisi bilgi paylaşımına yönelik tutumlarını pozitif olarak etkilemektedir $(B P Y T=\beta 0+\beta 1 K B)$.

\subsubsection{Bilgi Paylaşımına Yönelik Tutum ve Bilgi Paylaşma Davranışı}

Ryu vd. (2003:114)'nin belirttiği üzere Planlı Davranış Teorisi sosyal çerçevedeki birçok davranış türünü açıklamada kullanılmıştır (ör. Chang, 1998; Fortin, 2000; Sheppard vd, 1988). Ne var ki; bilgi paylaşımı alanında bu teorilerden çok sık yararlanılmamıştır. Bilgi yönetimi alanında sınırlı sayıda çalışma mevcuttur. Ryu ve arkadaşlarının (2003) hekimlerin bilgi paylaşma davranışlarını inceledikleri çalışmalarında, Planlı Davranış Teorisi kapsamında tutum ve davranış ilişkisi araştırarak hekimlerin bilgi paylaşma davranışları üzerinde bilgi paylaşımına yönelik tutumlarının anlamlı bir etkisi olduğunu göstermişlerdir. Bilgi paylaşma davranışını Planlı Davranış Teorisi çerçevesinde inceleyen başka bir çalışmada, Kore'deki 4 büyük kamu kurumunun 75 departmanındaki 467 kişi ile gerçekleştirilen anket çalışması sonucunda, beklenen ödül, beklenen ilişkive beklenen katkının bilgi paylaşımına yönelik tutumu, tutumun bilgi paylaşımına yönelik niyeti ve niyetin de bilgi paylaşma davranışını etkilediği bulunmuştur (Bock ve Kim, 2002). Chennemaneni (2006: 29)'nin çalışmasında geliştirilen model çerçevesinde de bilgi paylaşımına yönelik tutumun bilgi paylaşımına yönelik niyetler aracılığı ile bilgi paylaşma davranışını etkilediği iddia edilmiştir. Bu çalışmada da 213 kişinin 
katılımı ile bir anket çalışması gerçekleştirilmiş, çalışmanın sonucunda da yine bilgi paylaşımına yönelik tutumların bilgi paylaşımına yönelik niyetler aracılığı ile bilgi paylaşma davranışını etkilediği tespit edilmiştir. İlgili literatür doğrultusunda aşağıdaki hipotez oluşturulmuştur.

$\mathrm{H}_{4}$ :Bireylerin bilgipaylaşımınayönelik tutumları bilgi paylaşma davranışlarını pozitif olarak etkilemektedir $(B P D=\beta 0+\beta 1 B P Y T)$.

\section{ARAŞTIRMA METODOLOJISI}

\subsection{Araştırmanın Amacı ve Modeli}

Buaraştırmanın ana amacı,Türkiyegenelindeki 254 dermatologdan elde edilen verilerle hekimlerin bilgi paylaşma davranışını olumlu ve olumsuz etkileyen bazı bireysel faktörlerin planlı davranış teorisi ve sosyal değişim teorisi bağlamında incelenmesidir. Araştırma, "bilgi paylaşma" konusunda bireye ve davranışa odaklanan bir çalışma olmasıyla literatürdeki kısıtı sayıda çalışmanın yer aldığı bir alana yönelmektedir. İnsan yaşamının devamlılığı ve kalitesi açısından özel bir yere sahip olan hekimlik mesleğinde, bilgi paylaşma davranışını motive eden ya da engelleyen birtakım bireysel faktörleri belirleyerek söz konusu davranışı artırıcı önlemler alabilmek adına bu alanda yapılacak çalışmalara intiyaç duyulmaktadır.

Makale kapsamında ampirik olarak test edilmesi planlanan araştırma modeli ve hipotezler Şekil 2'de görülmektedir. Araştırmanın modeli, değişkenler arası doğrusal ve nedensel ilişkiye dayanmaktadır. Bağımlı değişkenler "bilgi paylaşımına yönelik tutum" ve "bilgi paylaşma davranışı"dır. "Bilgi paylaşımına yönelik tutum" değişkeninin "bilgi paylaşma davranışı"nı doğrudan etkilediği düşünülmektedir. Bilgi paylaşımına yönelik tutumun ise "kişisel çıktı beklentileri", "bilgi gücü kaybı beklentisi" ve "karşılık beklentisi" ile şekillendiği düşünülmektedir.

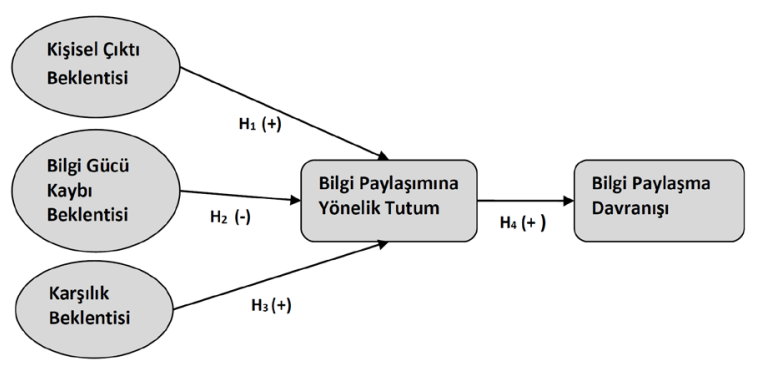

Şekil 2: Araştırmanın Modeli
Her çalışmanın olduğu gibi, bu çalışmanın da birtakım kısıtılıkları bulunmaktadır. Illk olarak bu çalışmanın ampirik kısmı kapsamında toplanan veri zamana yayılı değil, kesitsel bir veridir. Bu nedenle çalışmadan elde edilen bulgularla bir neden-sonuç ilişkisi kurarak yorum yapmak mümkün olmamış, yalnızca ihtimaller verilmiştir. Araştırma, yalnızca bilgi paylaşımı amacıyla kurulan sanal platforma (Facebook grubu) üye dermatologlar üzerinde yapıldığı için tüm sektörler ve meslek grupları için genellemelerde bulunulamayacağı gibi; söz konusu platforma üye olmayan dermatologların bilgi paylaşma davranışları hakkında da fikir vermeyebilir. Yine, araştırmaya kaynaklık eden cevapların kişilerin kendileri tarafından verilmiş olması, metot yanılgısına sebep olmuş olabilir.

Dolayısıyla daha genellenebilir sonuçlar için başka meslek, gruplarına ve farklı veri toplama yöntemleriyle çalışmalar yapılması gerekmektedir. Yine gelecek çalışmalarda bilgi paylaşma davranışına etki edebilecek çeşitli bireysel (mesleki öz-yeterlik, mesleğe bağlılık ve güven vb.), örgütsel (örgüt iklimi ve yönetici desteği vb.) ve durumsal (görev yapısı ve sosyal statü vb.) faktörler ele alınmalıdır. Özellikle bilgi paylaşımına yönelik öznel normlar, niyetler ve davranış kontrolünün de modele dâhil edilmesiyle bilgi paylaşımının planlı davranış teorisi kapsamında bütünüyle bir değerlendirmesini yapmak bağlamında bu çalışma bir başlangıç rolü üstlenebilecektir.

\section{2. Örneklem ve Veri Toplama}

Araştırmada evren olarak hekimler, örneklem olarak da hekimlik mesleğini icra eden bireylerden dermatoloji alanında uzmanlaşmış hekimler tercih edilmiştir. Hekimlik mesleğinin, bilgi paylaşımının hayati öneme sahip olduğu mesleklerden birisi olması örneklem olarak seçilmelerinde etkili olmuştur. Tüm insanlık için büyük önem arz eden ve aynı zamanda bilgi yoğun bir meslek olan hekimlikte bireyler arasında bilgi paylaşımı tüm insanlığın yaşam kalitesine katkı sağlayacaktır. Üstelik dermatoloji branşı, hem kitap, makale, vaka gibi açık bilgi kaynaklarından elde edilen bilgilerin hem de bireye özgü deneyim, beceri ve uzmanlığı kapsayan örtük bilgilerin önemli olduğu bir disiplindir. Ayrıca, dermatoloji hem "sağlık" hem de "güzellik" konusuna yöneldiği için, günümüzde hemen her bireyin ihtiyaç duyduğu bir alan konumundadır.

Elektronik ortamda hazırladığımı anket formunun 2014 yılı Nisan ve Mayıs ayları boyunca 
çeşitli zamanlarda Türkiye genelinde farklı şehirlerde yaşayan ve farklı birimlerde çalışan (kamu hastanesi, özel hastane ve muayenehane gibi) dermatologun oluşturduğu sanal platformda (Facebook grubu) paylaşılması suretiyle araştırma verileri elde edilmeye çalışılmışır. Söz konusu sanal platform, dermatologların internet üzerinden yeni tedaviler, yeni ürünler ve yeni yöntemler konusunda aktif bilgi paylaşımında bulunmaları ve çeşitli mesleki konuları tartışabilmeleri amacıyla kurulduğu için, üyelerin bilgi paylaşımı konusunda farkındalıklarının yüksek olduğu ve bu nedenle ankete gönüllü olarak katılacakları düşünülmüştür. Bilgi paylaşımının yakın ve sık ilişkilerle daha etkili olacağını iddia eden çalışmaların yanı sıra; daha fazlayeni bilgi sağlaması sebebiyle, uzak ve seyrek ilişkilerle daha etkin olacağını iddia eden çalışmaların varlığı dikkate alındığında (Hansen, 1999: 82), söz konusu sanal topluluk üyelerinin sağlayacağı bilgilerin araştırmamız için uygun olduğuna kanaat getirilmiştir. Ayrıca, çalışma yazarlarının yakınları arasında söz konusu platforma üye dermatologların bulunması veri toplama açısından bir avantaj olarak düşünülmüştür.

Anketin açıklamalar bölümünde değişkenlerin tanımları yapılarak anket cevaplayanlar için daha açık bir hale getirilmiştir. Tüm soruların cevaplanmaması halinde anketi tamamlamak mümkün olmadığından kayıp değer problemi ile karşılaşılmamış, cevaplanan anketlerin tümü tamamlanmış bir şekilde elde edilmiştir. Cevaplayıcıların IP numaraları, e-mail adresleri ve demografik özellikleri kontrol edilerek, aynı kişinin tekrarlı cevaplarının önüne geçilmeye çalışıımıştır. 2014 yılı Nisan ayı itibariyle, yaklaşık 1000 kişinin üye olduğu platformdan 658 kişi anketi görüntülemiş, 254 kişi soruların tümünü cevaplamış ve bu sayıdaki anket değerlendirmeye alınmıştır. Geri dönüş oranı $\% 25,4$ olmuştur.

\section{3. Ölçekler}

Araştırmada, katılımcılara 5 farklı ölçekten ve demografik sorulardan (yaş, cinsiyet, unvan ve çalıştığı birim) oluşan toplam 31 soru yöneltilmiştir. "Bilgi paylaşma davranışı"nı ölçmek için, çeşitli ölçekler incelenerek dermatologların bilgi paylaşma davranışlarını en uygun ve en kapsamlı şekilde ölçebilecek bir ölçek geliştirilmiştir. Çeşitli çalışmalar, bilgi paylaşma davranışını kendi özgün amaçları doğrultusunda ele aldıkları için, ölçek soruları araştırmanın amacına uygun olarak araştırmacılar tarafından Bock vd. (2005), Chennamaneni (2006),
Swift ve Virick (2013) çalışmalarından yararlanılarak oluşturulmuştur. Ölçekte, $5^{\prime}$ li Likert Ölçeği (1:Kesinlikle katılmıyorum, 5:Tamamen katılıyorum)'ne göre hazırlanmış 10 soru bulunmaktadır. Soruların 6'sı "Meslektaşlarımla eğitim ve öğrenimimden kaynaklanan uzmanlığımı paylaşıyorum" gibi açık bilgiyi; 4'ü ise, "meslektaşlarımla işimin püf noktalarını paylaşıyorum" gibi örtük bilgiyi ölçmeye yönelik sorulardır.

"Bilgi paylaşımına yönelik tutum"u ölçmek için, Bock vd. (2005)'nin, Fishbein ve Azjen (1975)'in Planlı Davranış Teorisi kapsamında geliştirmiş oldukları tutum ölçeğinin "bilgi paylaşımına yönelik tutum" konusuna uyarladıkları şekli kullanılmıştır. Ölçekte, 5’li Likert ölçeğine göre hazırlanmış "meslektaşlarım ile bilgi paylaşımım keyifli bir deneyimdir" gibi 5 soru bulunmaktadır.

“Kişisel çıktı beklentileri”, Chiu vd. (2006)'nin Bock ve Kim (2002) ve Hendriks (1999)'in çalışmalarından yararlanarak geliştirdiği ölçek kullanılarak ölçülmüştür. Ölçekte, 5'li Likert ölçeğine göre hazırlanmış "Meslektaşlarımla bilgi paylaşımım onlarla arkadaşlık kurmamı kolaylaştııı" gibi 5 soru bulunmaktadır. "Bilgi gücü kaybı beklentisi”ni ölçmek üzere, Kankanhalli vd. (2005)'nin geliştirmiş oldukları ölçek kullanılmıştır. Ölçekte, 5'li Likert ölçeğine göre hazırlanmış "Meslektaşlarımla bilgi paylaşmak mesleki camiadaki eşsizliğimin zedelenmesine neden olur" gibi 4 soru bulunmaktadır. "Karşılık beklentisi"ni ölçmek için ise, Chennamaneni (2006)'nin doktora tezi kapsamında Kankanhalli vd. (2005) ile Wasko ve Faraj (2005)'ın geliştirmiş olduğu ölçeklerden yararlanarak oluşturduğu ölçek kullanılmıştır. Ölçekte, 5'li Likert ölçeğine göre hazırlanmış "Meslektaşlarımla bilgimi paylaştığımda onlardan da benim bilgi intiyaçlarıma karşılık vermelerini bekliyorum" gibi 3 soru bulunmaktadır.

Ölçeklerin güvenilirlik ve geçerlilik analizleri kapsamında ilk olarak, iç tutarlılık için ölçeklerdeki ifadelerin ve her bir ölçeğin cronbach alpha katsayısı hesaplanmıştır. Ayrıca, toplam alfa değeri ile ölçeklerde yer alan her bir maddenin toplam ile ilişkisi ve madde çıkarıldığında ölçeğin alacağı değerlere de bakılmıştır. Analiz sonuçlarına göre, ölçeklerdeki ifadelerin 0,726 ile 0,938 arasında değişen değerler aldığı, tüm soruların ve ölçeklerin cronbach alpha değerlerinin (Tablo1) yazında önerilen kabul edilebilir düzey olan 0,60'ın üzerinde bulunduğu görülmüştür (Hair vd., 2000). 
Ölçeklerin geçerliliği kapsamında için ikinci olarak, yapı geçerliliğini test etmek için faktör analizi yapılmış ve soruların faktör yükleri kontrol edilerek doğru ölçek altında toplanıp toplanmadıkları incelenmiştir. Demografik verileri ölçen 4 ifade haricindeki 27 ifadeye uygulanan faktör analizi sonucunda öncelikle 6 bileşen elde edilmiştir. "Varimax Rotation" gerçekleştirilerek bileşenlerin altında toplanan ifadeler incelenmiş ve yalnızca bilgi paylaşma davranışı ölçeğindeki bir ifadenin ("Meslektaşlarımla işimin hilelerini paylaşıyorum") tek başına ayrı bir bileşende toplandığı gözlemlenmiştir. Bunun üzerine bu ifade analizden çıkartılarak tekrar faktör analizi yapılmıştır. Faktör analizi sonucuna göre, 26 ifade özdeğeri 1'den büyük 5 bileşen altında toplanarak uygun faktör analizi değerlerini vermiştir. $\mathrm{Bu}$ faktörlerin toplam varyansı açıklama yüzdesinin 72,033 olduğu ve soruların faktör yüklerinin ,507 ile ,919 arasında değiştiği görülmüştür. Ayrıca, örneklem yeterliliğini ölçen KMO testi sonucu 0.898, Bartlett küresellik testi de anlamlı bulunmuştur $(p<0.001)$. Buna göre, değişkenler arasında yüksek düzeyde korelasyonlar bulunduğu ve veri setinin faktör analizi için uygun olduğuna kanaat getirilmiştir. Faktör analizi sonucu oluşan bileşenler ve faktör yükleri Tablo 1'de gösterilmiştir.

Tablo 1: Faktör Analizi, Güvenilirlik ve Tanımlayıcı İstatistik Sonuçları

\begin{tabular}{|c|c|c|c|c|c|c|c|c|}
\hline Ölçekler & $\begin{array}{c}\text { Soru } \\
\text { No }\end{array}$ & $\begin{array}{l}\text { Faktör } \\
\text { Yükleri }\end{array}$ & $\begin{array}{l}\text { Açıklanan } \\
\text { Varyans }\end{array}$ & $\begin{array}{l}\text { Cronbach } \\
\text { Alpha }\end{array}$ & Ort. & S.Sapma & Çarpıklık & Basıklık \\
\hline \multirow{9}{*}{ 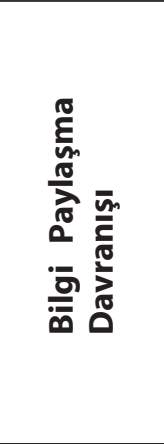 } & d1 & 840 & \multirow{9}{*}{24,289} & \multirow{9}{*}{,938 } & 4,2402 & 74481 &,- 999 & 1,556 \\
\hline & $d 2$ & 816 & & & 4,1811 & 81892 & -,999 & 1,213 \\
\hline & d3 & 751 & & & 3,9528 & 93975 &,- 827 & ,433 \\
\hline & d4 & 731 & & & 4,2047 & 86512 & $-1,406$ & 2,622 \\
\hline & d5 & 845 & & & 4,2283 & 76162 &,- 952 & 1,220 \\
\hline & $d 6$ & 860 & & & 4,3150 & 71903, & $-1,067$ & 1,825 \\
\hline & d7 & 849 & & & 4,2598 & 75142 &,- 975 & 1,292 \\
\hline & $\mathrm{d} 8$ & 789 & & & 4,2087 & 84334 & $-1,248$ & 2,152 \\
\hline & $\mathrm{d} 10$ & ,730 & & & 4,3425 & ,73102 & $-1,184$ & 2,030 \\
\hline \multirow{5}{*}{ 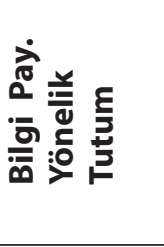 } & $\mathrm{t} 1$ & 809 & \multirow{5}{*}{12,665} & \multirow{5}{*}{852} & 4,6929 & ,54100 & $-2,326$ & 9,453 \\
\hline & t2 & ,507 & & & 4,8150 & 46329 & $-3,495$ & 19,013 \\
\hline & t3 & 839 & & & 4,5984 & 61290 & $-1,887$ & 5,748 \\
\hline & t4 & 799 & & & 4,6024 & 64984 & $-2,259$ & 7,764 \\
\hline & t5 & ,586 & & & 4,3976 & ,78231 & $-1,429$ & 2,441 \\
\hline \multirow{5}{*}{ 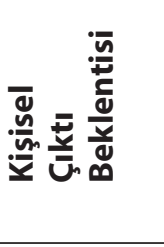 } & çb1 & 796 & \multirow{5}{*}{13,046} & \multirow{5}{*}{879} & 4,1811 & 77935 &,- 884 & ,953 \\
\hline & çb2 & ,570 & & & 4,4488 & 61224 & $-1,157$ & 3,438 \\
\hline & çb3 & 866 & & & 3,9016 & 90789 &,- 475 & -130 \\
\hline & çb4 & 830 & & & 4,1220 & 81783 &,- 710 & ,234 \\
\hline & çb5 & 681 & & & 4,3228 & ,73728 &,- 892 & ,404 \\
\hline \multirow{4}{*}{ 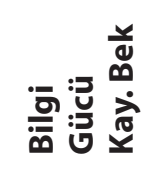 } & bg1 & 891 & \multirow{4}{*}{12,993} & \multirow{4}{*}{879} & 1,4016 & 73597 & 2,623 & 8,734 \\
\hline & bg2 & 919 & & & 1,3543 & 64148 & 2,596 & 9,626 \\
\hline & bg3 & 868 & & & 1,3937 & 72404 & 2,329 & 6,407 \\
\hline & bg4 & ,882 & & & 1,3661 & 66222 & 2,478 & 8,384 \\
\hline \multirow{3}{*}{ 苛 } & kb1 & ,854 & \multirow{3}{*}{9,040} & \multirow{3}{*}{849} & 3,2795 & 1,18481 &,- 413 &,- 736 \\
\hline & kb2 & ,883 & & & 3,5394 & 1,01200 &,- 477 &,- 277 \\
\hline & kb3 & ,835 & & & 3,7244 & 1,01512 &,- 705 & ,088 \\
\hline \multicolumn{2}{|c|}{ Toplam Varyans } & \multicolumn{7}{|l|}{$\% 72,033$} \\
\hline \multicolumn{2}{|l|}{ KMO Testi } & \multicolumn{7}{|l|}{0,898} \\
\hline \multicolumn{2}{|c|}{ Bartlett testi } & \multicolumn{7}{|l|}{0,000} \\
\hline
\end{tabular}


Ölçeklerin yapı geçerliliği için son olarak, ölçek faktör yapılarının doğrulanıp doğrulanmadığı test edilmiştir. Her ne kadar, araştırmada kullanılan ölçekler daha önce çeşitli çalışmalarda kullanılan geçerlilik ve güvenilirlikleri test edilmiş ölçekler olsa da, araştırmanın amaçları doğrultusunda uyarlamalar yapıldığı için, doğrulayıcı faktör analizine de gerek görülmüştür. Bunun için AMOS 20 programında doğrulayıcı (confirmatory) faktör analizi yapılmıştır. Uyum iyiliği değerlerine ilişkin yaygın şekilde kabul edilen görüşe göre CMIN/DF oranının 5'den küçük, RMSEA'nın 0,08'den küçük, GFI, AGFI VE CFI'nın 0,90'dan büyük olması kabul edilebilir uyuma; CMIN/ DF oranının 3'den küçük, RMSEA'nın 0,05'den küçük, GFI, AGFI VE CFI'nın 0,95'den büyük olması iyi uyuma işaret etmektedir (Bayram, 2010: 78; Çelik ve Yılmaz, 2013:39). Tablo 2'de sunulan sonuçlar incelendiğinde araştırma değişkenlerinin doğrulayıcı faktör analizine dair elde edilen uyum iyiliği değerlerinin yazında kabul gören değerlere uygun olduğu görülmektedir. Ayrıca, doğrulayıcı faktör analizi sonucunda verilerin ölçeklerin tek faktörlü yapısına uyum sağladığı görülmüştür. Bilgi paylaşma davranışı ölçeği hem açık bilgi hem de örtük bilgiyi ölçecek soruları barındırmasına rağmen, açıklayıcı ve doğrulayıcı faktör analizi sonuçları ölçeğin tek boyutlu olduğunu ortaya koymuştur. Bu nedenle, araştırmada bilgi paylaşma davranışı açık ve örtük bilgi paylaşımı alt boyutları bağlamında ayrı ayrı incelenmeyerek tek bir ölçek olarak ele alınmıştır.

Tablo 2: Ölçeklerin Doğrulayıcı Faktör Analizi Sonuçlarına Ait Uyum İyiliği Sonuçları

\begin{tabular}{lccccc}
\hline Ölçekler & CMIN/DF & RMSEA & GFI & AGFI & CFI \\
\hline Bilgi Paylaşma Davranışı* & 2,095 &, 066 &, 959 &, 924 &, 985 \\
Bilgi Paylaşma Dav. Yönelik Tutum* & 2,217 &, 069 &, 992 &, 958 &, 996 \\
Kişisel Çıktı Beklentisi* $^{*}$ & 1,628 &, 050 &, 990 &, 963 &, 996 \\
Bilgi Gücü Kaybı Beklentisi* & 2,503 &, 077 &, 990 &, 949 &, 996 \\
Karşılık Beklentisi* $^{\text {Kabul Edilebilir Uyum** }}$ &, 000 &, 000 & 1,000 & 1,000 & 1,000 \\
\hline İyi Uyum** & $\leq 5$ & $\leq 0.08$ & $\geq 0.90$ & $\geq 0.90$ & $\geq 0.90$ \\
\hline
\end{tabular}

*Tek faktörlü yapı, ** Kaynak: Bayram, 2010:78; Çelik ve Yılmaz, 2013:39.

\subsection{Bulgular}

\subsubsection{Demografik Verilere iliş̧kin Bulgular}

Araştırmada, analize konu olan demografik değişkenler cevaplayanın cinsiyeti, yaşı, unvanı ve çalıştığı kurumun niteliğidir. Demografik değişkenlere ilişkin bulgular, aşağıdaki Tablo 3'te toplu olarak görülmektedir. Tabloda dikkat çeken husus, cevaplayanlar arasındaki kadın oranının yüksekliğidir. Bu durumun dermatologluk mesleğinin özellikle geçmişte daha çok kadınlara uygun bir alan olarak görülmesi ile ilgili olduğu düşünülmektedir. Diğer bir dikkat çekici bulgu uzman doktor oranının yüksek olmasıdır.
Tablo 3: Demografik Değişkenlere İlişkin Bulgular

\begin{tabular}{llcc}
\hline Özellik & Boyutlar & Sayı & Yüzde (\%) \\
\hline \multirow{2}{*}{ Cinsiyet } & Kadın & 205 & 80,7 \\
& Erkek & 49 & 19,3 \\
\hline \multirow{3}{*}{ Yaş } & $20-30$ & 38 & 15,0 \\
& $31-40$ & 107 & 42,1 \\
& $41-50$ & 80 & 31,5 \\
& $50+$ & 29 & 11,4 \\
\hline \multirow{3}{*}{ Unvan } & Asistan & 23 & 9,1 \\
& Uzman & 191 & 75,2 \\
& Yrd. Doç. Dr. & 16 & 6,3 \\
& Doç./ Prof. Dr. & 24 & 9,4 \\
\hline \multirow{4}{*}{ Çalıştığı } & Vukıf Ün. & 11 & 4,3 \\
& Devlet Ün. & 53 & 20,9 \\
& Özel Hastane & 61 & 24,0 \\
& Devlet Hastanesi & 88 & 34,6 \\
& Muayenehane & 23 & 9,1 \\
& Diğer & 18 & 7,1 \\
\hline Toplam & & 254 & 100 \\
\hline
\end{tabular}


Hipotez testlerine geçmeden önce, fark testleri yapılarak örneklemin demografik özellikleri ile değişkenler arasında bir farklııık olup olmadığına bakılmıştır. Yapılan t-testi sonucuna göre, araştırma değişkenleri ile cevaplayıcıların cinsiyeti arasında anlamlı bir farklılık bulunmamıştır. Yaş, unvan ve çalışılan kurum ile değişkenler arasında farklılık olup olmadığını test etmek için yapılan ANOVA sonucuna göre ise; çalışılan kurum ile ilgili anlamlı bir farklılık görülmezken; yaş ve unvan değişkeni bakımından farklılık bulunmuştur $(p<0,05)$. Bu farklıığın nereden kaynaklandığına yönelik yapılan Tukey çoklu karşılaştırma testinin sonucuna göre; yaşı 20-30 aralığında olanların bilgi paylaşma davranışına yönelik puanlarının düzeyi, yaşı 50'den büyük olanlara göre daha düşük olduğu görülmüştür (Ortalama Farkı: $-4,9109 ; p<0,05)$. Unvana göre yapılan karşılaştırma testinin sonucuna göre ise, unvanı doçent ve profesör olan hekimlerin, unvanı asistan olan hekimlere göre daha fazla bilgi paylaşma davranışı gösterdikleri bulunmuştur (Ortalama Farkı: $6,9161 ; p<0,05)$. Bir başka ifadeyle, yaş ve unvan olarak daha deneyimli hekimlerin bilgi paylaşma davranışı gösterme eğilimlerinin gençlere oranla arttığı gözlenmiştir.

\subsubsection{Hipotez Testlerine Iilişkin Bulgular}

Araştırma sonucunda elde edilen verilere SPSS 21 paket programında analizler yapılmıştır. Bu kapsamda, ilk olarak değişkenlerin ortalamaları, standart sapmaları ve aralarındaki korelasyonlara bakılmış; daha sonra, araştırma modelindeki hipotezleri test etmek için regresyon analizi yapılmıştır. Elde edilen ortalamalar, standart sapmalar ve Tablo1'de; korelasyon değerleri ise Tablo 4'de görülmektedir. Buna göre tüm değişkenler arasındaki beklenen korelasyonlar gözlemlenmiştir. Illk olarak bilgi paylaşma davranışı ile bilgi paylaşımına yönelik tutum arasındaki orta seviyede anlamlı ve pozitif bir korelasyon gözlemlenmektedir ( $r=, 469$; $\mathrm{p}<$,001). Diğer değişkenler ile tutum arasında da anlamlı ilişkiler mevcuttur. Beklendiği gibi kişisel çıktı beklentileri ve karşılık beklentisi ile bilgi paylaşımına yönelik tutum arasında pozitif korelasyonlar gözlemlenirken bilgi gücü kaybı beklentisi ile bilgi paylaşımına yönelik tutum arasında negatif korelasyon gözlemlenmiştir. Her ne kadar bu değişkenlerle bilgi paylaşma davranışı arasında da anlamlı korelasyonlar gözlemlenmekteyse de bu korelasyonların katsayılarının bu değişkenlerin bilgi paylaşımına yönelik tutum ile aralarındaki korelasyon katsayılarından küçük olması bize "Planlı Davranış Teorisi"nin modele uygulanmasının doğru bir karar olduğunu göstermektedir.

Tablo 4: Tanımlayıcı İstatistikler ve Korelasyonlar

\begin{tabular}{|c|c|c|c|c|c|c|c|}
\hline Boyut & Ort. & S.S. & 1 & 2 & 3 & 4 & 5 \\
\hline Bilgi Paylaşma Dav.(1) & 37,93 & 5,88 & 1 & & & & \\
\hline Bilgi Pay. Yön. Tutum (2) & 23,11 & 2,45 & $469^{* *}$ & 1 & & & \\
\hline Kişisel Çıktı Beklentisi(3) & 20,98 & 3,19 & $394^{* *}$ &, $572^{* *}$ & 1 & & \\
\hline Bilgi Gücü Kaybı Bek. (4) & 5,56 & 2,50 &,$- 132^{*}$ &,$- 312^{* *}$ &,$- 151^{*}$ & 1 & \\
\hline Karşılık beklentisi & 10,54 & 2,82 & ,094 &, $231 * *$ &, $328^{* *}$ & , 122 & 1 \\
\hline
\end{tabular}

${ }^{* *} p<0,01{ }^{*} p<0,05(N=254)$

Korelasyon analizi ile değişkenler arasında ilişki saptandıktan sonra, bu ilişkileri test etmek için diğer analizlere geçilmiştir. Regresyon analizinden önce verinin analize uygun olup olmadığını gözlemlemek üzere birtakım testler gerçekleştirilmiştir. Regresyon analizi yapabilmek için, verinin çok değişkenli normal dağılıma sahip olması önemli bir varsayımdır (Akgül ve Çevik, 2005:309). Bunun için, öncelikle normallik testi gerçekleştirilerek verilerin ve artıkların normal veya normale yakın dağıldığı gözlemlenmiştir. Daha sonra otokorelasyon problemi yaşanıp yaşanmadığını anlamak için Durbin-Watson (D-W) istatistiği sonuçlarına bakılmış ve 1,782 sonucu elde edilerek bu problemin yaşanmadığı anlaşılmıştır. Son olarak çoklu doğrusal bağlantı sorunu olup olmadığını belirlemek maksadıyla doğrudaşlığa (collinearity) da bakılarak, 5'in altında VIF değerleri 0,20'nin üzerinde tolerans değerleri elde edilmiş ve çoklu bağlantı problemi de yaşanmadığına kanaat getirilmiştir (Akgül ve Çevik, 2005:307-316). 
Yapılan çoklu doğrusal regresyon analizi üzerindeki etkisi ile ilgili anlamlı bir regresyon modeli sonucunda, kişisel çıktı beklentileri, bilgi gücü kaybı beklentisi ve karşılık beklentisi bağımsız değişkenlerinin bilgi paylaşımına yönelik tutum

elde edilmiştir $(F=43,461 ; p<, 001)$. İlgili regresyon denklemi ve analiz sonuçları Tablo 5'te görülmektedir.

Tablo 5: Kişisel Çıktı, Bilgi Gücü Kaybı ve Karşılık Beklentilerinin Bilgi Paylaşımına Yönelik Tutum Üzerindeki Etkisini Gösteren Regresyon Analizi Sonuçları

\begin{tabular}{|c|c|c|c|c|c|c|c|}
\hline \multicolumn{8}{|c|}{ Model $1^{1 *}:$ BPDYT $=\beta 0+\beta$ 1KÇB $+\beta 2 B G K B+\beta 3 K B$} \\
\hline \multirow[t]{2}{*}{ Bağımsız Değişkenler } & \multicolumn{2}{|c|}{$\begin{array}{l}\text { S. Edilmemiş } \\
\text { Katsayılar }\end{array}$} & \multirow{2}{*}{$\begin{array}{c}\begin{array}{c}\text { Standardize } \\
\text { Katsayılar }\end{array} \\
\beta \\
\end{array}$} & \multirow[t]{2}{*}{$\mathbf{t}$} & \multirow[t]{2}{*}{$\mathbf{P}$} & \multicolumn{2}{|c|}{ Collinearity } \\
\hline & B & S.Hata & & & & Tolerans & VIF \\
\hline Sabit (Constant) & 13,512 & 1,083 & & 12,471 & ,000 & & \\
\hline Kişisel Çıktı Bek. (KÇB) & 0,339 & 0,043 & 0,441 & 7,859 &, $000^{* *}$ & ,751 & 1,332 \\
\hline Bilgi Gücü Kaybı Bek.(BGKB) & $-0,250$ & 0,049 & $-0,255$ & $-5,093$ &, $000^{* *}$ & 943 & 1,060 \\
\hline Karşılık Beklentisi ( KB) & 0,092 & 0,046 & 0,106 & 2,019 &, $045^{*}$ & 860 & 1,163 \\
\hline $\mathrm{R}^{2}$ & 0,411 & & & & & & \\
\hline Düzeltilmiş $\mathrm{R}^{2}$ & 0,402 & & & & & & \\
\hline $\mathrm{F}$ & 43,461 & & & & & & \\
\hline Anlam Düzeyi & 0,000 & & & & & & \\
\hline Durbin-Watson İstatistiği & 1,782 & & & & & & \\
\hline
\end{tabular}

Bağımlı Değişken: Bilgi Paylaşımına Yönelik Tutum $\quad{ }^{* *} p<0,001 ;{ }^{*} p<0,05$

Analiz sonucuna göre, bağımsız değişkenlerin sıfır değerine karşılık bağımlı değişkenin alacağı değeri ve regresyon doğrusunun bağımlı değişkenle kesiştiği yeri ifade eden sabit terim 13,512 olarak bulunmuştur. Modelin etkinliğini gösteren $\mathrm{R}^{2}$ değeri 0,411 olarak bulunmuş ve modeldeki bağımsız değişkenlerin, bağımlı değişkenin toplam varyansının yaklaşık \% 41,1'ini açıkladığı görülmüştür. Modelin genellenebilirliğini gösteren düzeltilmiş $\mathrm{R}^{2}$ değerinin ise, 0,402 olduğu ve toplam varyansın \% 40,2'sini açıkladığı görülmüştür. $R^{2}$ değerinin bire yakın olması modelin uyum iyiliğinin uygun olduğu şeklinde değerlendirilse de, bağımsız değişken sayının birden çok olduğu modellerde $\mathrm{R}^{2}$ değerinin yeterli olmadığı ve düzeltilmiş $\mathrm{R}^{2}$ değerine göre yorum yapılmasının daha doğru olacağı ifade edilmektedir (Akgül ve Çevik, 2005: 333).

Düzeltilmiş $\mathrm{R}^{2}$ üzerindeki etkinin gücü açısından değişkenlere baktığımızda (Tablo 5), bağımsız değişkenlerden kişisel çıktı beklentilerinin dermatologların bilgi paylaşımına yönelik tutumlarını anlamlı ve olumlu olarak etkilediği görülmektedir $(\beta=, 441 ; p<0,001)$. Bu sonuç, Hsu vd., (2007), Kankanhalli vd. (2005) ve Wasko ve Faraj (2000)'ın itibar artışı, başarı, arkadaş edinme, vb. kazanımlarını içeren kişisel çıktı beklentilerinin düzeyi arttıkça, bilgi paylaşmaya yönelik tutumlarının düzeyinin de artacağını ifade eden literatür bulgularıyla örtüşmektedir. Böylece araştırmanın birinci hipotezi (H1) doğrulanmış olmaktadır.

Yine, Tablo 5'te araştırmanın bağımsız değişkenlerinden bilgi gücü kaybı beklentisinin dermatologların bilgi paylaşımına yönelik tutumlarını anlamlı ve negatif olarak etkilediği görülmektedir ( $\beta=$ $-, 255 ; p<0,001)$. Bir başka ifadeyle, dermatologlar bilgi paylaşımının diğer meslektaşları karşısında sahip oldukları özel konumlarını kaybetme ve bireysel güçlerini yitirmelerine neden olacağını düşünürlerse, bilgi paylaşımına yönelik tutumları negatif olacaktır. Bu sonuç, çeşitli zorluklar sonucunda elde edilen bilginin paylaşılırsa ona sahip olan bireyin yeri doldurulamazlık özelliğinin azalacağı bu nedenle de bilgisini paylaşmama eğilimi göstereceğini ifade eden literatürdeki pek çok çalışma sonucunu destekler niteliktedir (Gray, 2001; Szulanski, 1996; Bartol ve Srivastava, 2002). Benzer şekilde, Wasko ve Faraj (2005), bilgi paylaşımında bilgiyi paylaşan kişi hariç herkesin yarar gördüğüne dikkati çekerek, bilgi gücü kaybı beklentisinin bilgi paylaşmaya yönelik tutumları olumsuz etkileyeceğini ifade etmiştir.

*BPYT=Bilgi Paylaşma Davranışına Yönelik Tutum, KÇB= Kişisel Çıktı Beklentileri, $\mathrm{BGKB}=$ Bilgi Gücü Kaybı Beklentileri, KB=Karşılık Beklentileri 
Dolayısıyla, bu sonuca göre araştırmanın ikinci hipotezi $\left(\mathrm{H}_{2}\right)$ doğrulanmış olmaktadır.

Araştırmanın, dermatologların karşılık beklentisinin bilgi paylaşımına yönelik tutumlarına etkisini test eden üçüncü hipotezinin $\left(\mathrm{H}_{3}\right)$ sonuçları Tablo 5'de görülmektedir. Buna göre, dermatologların karşılıkbeklentisi, bilgi paylaşımınayöneliktutumlarını anlamlı ve pozitif olarak etkilemektedir $(\beta=, 106$; $p<0,005)$. Yani, karşısındakilerle değerli bilgisini paylaşan hekim, karşıı̆ı̆ıda başka değerli bilgiler elde edebileceğini düşünürse bilgi paylaşımına karşı olumlu bir tutum geliştirebilecektir. Yine bu sonuç da, karşılık beklentisi ne kadar büyük olursa, bilgi paylaşımına yönelik tutumun da o denli olumlu olacağını ifade eden çeşitli araştırma sonuçlarıyla örtüşmektedir (Hall, 2001; Kwok ve Gao, 2004; Bock ve Kim (2002). Böylece, araştırmanın üçüncü hipotezi $\left(\mathrm{H}_{3}\right)$ de doğrulanmış olmaktadır.

Tablo 6: Bilgi Paylaşımına Yönelik Tutumun Bilgi Paylaşma Davranışı Üzerindeki Etkisini Gösteren Regresyon Analizi Sonuçları

\begin{tabular}{|c|c|c|c|c|c|c|c|}
\hline \multicolumn{8}{|c|}{ Model $2^{2^{*}}:$ BPD $=\beta_{0}+\beta_{1}$ BPDYT } \\
\hline \multirow[t]{2}{*}{ Bağımsız Değişken } & \multicolumn{2}{|c|}{$\begin{array}{l}\text { S. Edilmemiş } \\
\text { Katsayılar }\end{array}$} & \multirow{2}{*}{$\begin{array}{c}\begin{array}{c}\text { Standardize } \\
\text { Katsayılar }\end{array} \\
\beta\end{array}$} & \multirow[t]{2}{*}{$\mathbf{t}$} & \multirow[t]{2}{*}{$\mathbf{P}$} & \multicolumn{2}{|c|}{ Collinearity } \\
\hline & B & S.Hata & & & & Tolerans & VIF \\
\hline Sabit (Constant) & 11,902 & 3,103 & & 3,835 & ,000 & & \\
\hline $\begin{array}{l}\text { Bilgi Paylaşımına } \\
\text { Yönelik Tutum (BPYT) }\end{array}$ & 1,127 & 0,134 & 0,469 & 8,435 &, $000^{* * *}$ & 1,000 & 1,000 \\
\hline $\mathrm{R}^{2}$ & 0,220 & & & & & & \\
\hline Düzeltilmiş $\mathrm{R}^{2}$ & 0,217 & & & & & & \\
\hline $\mathrm{F}$ & 71,154 & & & & & & \\
\hline Anlam Düzeyi & 0,000 & & & & & & \\
\hline Durbin Watson & 1,954 & & & & & & \\
\hline
\end{tabular}

Bağımlı Değişken: Bilgi Paylaşma Davranışı **** $p<0,001$

Son olarak, araştırmanın dördüncü hipotezini test etmek için yapılan basit doğrusal regresyon analizi sonuçları ve regresyon denklemi Tablo 6'da görülmektedir. Analiz sonucuna göre, bilgi paylaşımına yönelik tutumun bilgi paylaşma davranışı üzerindeki etkisi ile ilgili anlamlı bir regresyon modeli elde edilmiştir ( $F=71,154 ; p<0,001) . R^{2}$ değeri 0,220 ; düzeltilmiş $R^{2}$ değeri ise 0,217 olarak bulunmuştur. Analiz sonucuna göre, bilgi paylaşımına yönelik tutumun bilgi paylaşma davranışını pozitif yönde ve istatistikî olarak anlamlı bir şekilde etkilediği $(\beta=, 469$; $p<, 001)$ ve bu sonucun literatürdeki çeşitli araştırma sonuçlarıyla uyumlu olduğu görülmektedir (Bock ve Kim, 2002; Ryu vd., 2003; Chennemaneni, 2006). Dolayısıyla, araştırmanın dördüncü hipotezi $\left(\mathrm{H}_{4}\right)$ de doğrulanmıştır.

\section{SONUÇ ve TARTIŞMA}

$\mathrm{Bu}$ araştırmada, Türkiye genelinde 254 dermatologdan elde edilen nicel verilerle, bilgi paylaşma davranışına etki eden bazı faktörler oluşturulan bir araştırma modeli yardımıyla incelenmiştir ve ortaya çıkan bulgular ilgili literatürle karşılaştırılarak yorumlanmıştır. Araştırmanın ilk hipotezi $\left(H_{1}\right)$, itibar kazanma, arkadaş edinme, mutluluk hissi yaşama, vb. manevi kazanımları ifade eden kişisel çıktı beklentilerinin bilgi paylaşımına yönelik tutumu pozitif yönde etkileyeceğini söylemektedir ve bu hipotez doğrulanmıştır. Bu sonuç literatürdeki çok sayıdaki benzer bulguyu (Constant vd, 1994; Hsu vd, 2007; Kankanhalli vd, 2005; Kwok ve Gao, 2004; Wasko ve Faraj, 2000) doğrulamaktadır.

İkinci hipotez $\left(\mathrm{H}_{2}\right)$, bilgi gücü kaybı beklentisinin bilgi paylaşımına yönelik tutumu olumsuz etkilediğini söylemektedir ve bu hipotez de doğrulanmıştır. Literatürdeki pek çok çalışmada bilgi gücü kaybı beklentisinin bilgi paylaşımına yönelik tutumu negatif yönde etkilediği ifade edilmektedir (Bartol ve Srivastava, 2002; Husted ve Michailova, 2002; Szulanki, 1996) ve bu çalışma da literatürdeki bu bulguyu doğrular niteliktedir. Bunun nedeni olarak bilginin tek sahibi olma isteği (Gray, 2001: 369), söz konusu bilgiye sahip olmaktan kaynaklanan üstünlüğünü kaybetme korkusu (Szulanski, 1996: 31), yeri doldurulamazlık 
özelliğinin yok olacağını düşünme (Kankanhalli vd, 2005: 118) vb. gösterilmiştir.

Araştırmadaki üçüncü hipotez $\left(\mathrm{H}_{3}\right)$, karşılık beklentisinin bilgi paylaşımına yönelik tutumu pozitif yönde etkilediği söylemektedir. Hall (2001), Cohen (1998), Kwok ve Gao (2004) ve Wasko ve Faraj (2005) vb. pek çok çalışma bireyin karşılığında benzer davranışı görme beklentisi ile bilgi paylaşıma davranışı gerçekleştirdiğini belirtmiştir. Bu anlamda karşılık beklentisi sosyal değişimde anahtar bir rol üstlenebilmektedir (Wasko ve Faraj, 2005: 43). Bu çalışmaları doğrular bir şekilde, yapılan ampirik uygulamanın sonucu da karşılık beklentisinin bilgi paylaşımına yönelik tutum üzerindeki pozitif yönlü anlamlı etkisini göstermektedir.

Son olarak, dördüncü hipotez $\left(\mathrm{H}_{4}\right)$ planlı davranış teorisinden yola çıkarak bilgi paylaşımına yönelik tutumun bilgi paylaşma davranışını pozitif yönde etkilediğini söylemektedir. Bilgi paylaşımını planlı davranış teorisi kapsamında incelemeye alan birtakım çalışmalar mevcuttur ve bu çalışmaların genelinde bilgi paylaşımına yönelik tutumun bilgi paylaşımı üzerindeki olumlu etkisi tespit edilmiştir (Bock ve Kim, 2002; Ryu vd., 2003; Chennemaneni, 2006). Bu çalışmada da, bilgi paylaşımına yönelik tutumun bilgi paylaşma davranışını olumlu yönde etkilediği bulunmuştur. Ne var ki yapılan regresyon analizine ait $R^{2}$ değeri düşük çıkmıştır $\left(R^{2}=0,220\right)$. Bu durum bilgi paylaşımına yönelik tutumun bilgi paylaşma davranışı değişkenindeki varyansı açıklamada yetersiz kaldığını göstermektedir. Bu durumun olası nedeni, birtakım çalışmalarda (örn. Chennemaneni, 2006; Ryu vd, 2003) yapılanın aksine, bu çalışmada, bilgi paylaşımına yönelik öznel normlar ve algılanan davranış kontrolü ve davranışa yönelik niyetin modele dâhil edilmemiş olması olabilecektir.

Araştırmanın bulgularına ve yapılan değerlendirmelere dayanarak birtakım önerilerde bulunmak mümkün olabilecektir. Bu araştırmanın sonuçlarına dayanarak mesleki bilgi paylaşımını artırmak adına içsel motivasyonlara dayanan kişisel çıktı beklentilerine özel bir önem verilmesi gerektiği anlaşılmaktadır. Meslek sahipleri özellikle bilgi paylaşımları sonucunda itibarlarının artacağını ve arkadaş edineceklerini düşünüyorlarsa daha fazla bilgi paylaşma eğiliminde olacaklardır. Ek olarak, "bilgi güçtür" algısı bağlamında bireylerin bilgilerini kendilerine saklama eğiliminde olmaları bilgi paylaşımının önündeki engellerdendir. Bunu aşmak adına, bilginin kişiye değil topluma ve söz konusu mesleğe ait olduğu algısının yerleştirilmesinin bireylerin bilgi paylaşma davranışa olumlu etki yapması mümkün olabilecektir. Ayrıca paylaşılan bilgi ile güç kaybı yaşanmayacağının, aksine itibar kazanımı ile gücün artacağının gösterilmesi de bireylerin bilgi paylaşımına olumsuz bakmalarını engelleyebilecektir. Dahası, bireyler arasında karşılıklı güvenin sağlandığı ortamlarda bilgi paylaşımının daha fazla olacağını söylemek mümkündür çünkü bireyler karşılığını görecek olma beklentisi ile de bilgi paylaşmaktadırlar. $\mathrm{Bu}$ durumda bireyin karşısındakine olan güveni bilgi paylaşımını artırıcı bir rol üstlenecektir. Pratik anlamda bilgi paylaşımı zorla gerçekleştirilemez, yalnızca desteklenebilir ve iyileştirilebilir. Dolayısıyla da üyelerinin bilgi paylaşma davranışlarını artırmak isteyen örgütlerin karşı karşıya kaldığı en önemli sorun insanların davranışını değiştirmektir. Bilgi paylaşımında bilgi sağlayıcıların faydalarının artırılıp maliyetlerinin azaltılması, bu bireylerin bilgi sağlama davranışlarının artışını sağlayabilecektir.

Araştırmanın sonuçları, araştırma modelini doğrulamış ve dermatologların bilgi paylaşma davranışlarını tahmin etmede Planlı Davranış Teorisi ve Sosyal Değişim Teorisinin açıklayıcı etkisini ortaya koymuştur. 


\section{KAYNAKLAR}

Ajzen, I. (1985) From Intentions to Actions: A Theory of Planned Behavior. Julius Kuhl ve Jürgen Beckmann (Editörler) "Action Control", 11-39. Springer Berlin Heidelberg.

Ajzen, I. (1991) "The Theory of Planned Behavior" Organizational Behavior and Human Decision Processes, 50 (2), 179-211.

Ajzen, I. ve Fishbein, M. (1977) "Attitude-Behavior Relations: A Theoretical Analysis and Review of Empirical Research" Psychological Bulletin, 84 (5), 888.

Akgül, A. ve Çevik, O. (2005) İstatistiksel Analiz Teknikleri, SPSS'te Işletme Yönetimi Uygulamaları, 2. Baskı, Ankara:Emek Ofset Ltd. Şti.

Aydıntan, B., Göksel, A. ve Bingöl, D. (2010) "Örtülü Bilgi Paylaşım Niyeti Üzerinde Sosyal Sermaye Ve Denetim Merkezi Odaklılığının Rolü: Hekimlikte Bir Alan Araştırması" Gazi Üniversitesi IiBF Dergisi, 12 (1), $1-26$.

Bartol, K. M. ve Srivastava, A. (2002) "Encouraging Knowledge Sharing: The Role of Organizational Reward Systems" Journal of Leadership \& Organizational Studies, 9(1), 64-76.

Bayram, N. (2010) Yapısal Eşitlik Modellemesine Giriş AMOS Uygulamaları. Ankara:Ezgi Kitabevi.

Bentler, P. M. ve Speckart, G. (1979) "Models of Attitude-Behavior Relations" Psychological Review, 86 (5), 452.

Bock, G. W. ve Kim, Y. G. (2002) "Breaking the Myths of Rewards: An Exploratory Study of Attitudes About Knowledge Sharing" Information Resources Management Journal (IRMJ), 15(2), 14-21.

Bock, G. W., Zmud, R. W., Kim, Y. G. ve Lee, J. N. (2005) "Behavioral Intention Formation in Knowledge Sharing: Examining the Roles of Extrinsic Motivators, Social-Psychological Forces, and Organizational Climate" MIS Quarterly, 29 (1), 87-111.

Chang, M. K. (1998) "Predicting Unethical Behavior: A Comparison of the Theory of Reasoned Action and the Theory of Planned Behavior" Journal of Business Ethics, 17 (16), 1825-1834.

Chennamaneni, A. (2006) "Determinants of Knowledge Sharing Behaviors: Developing and Testing an Integrated Theoretical Model" Yayınlanmamış Doktora Tezi, Teksas Üniversitesi.

Chiu, C. M., Hsu, M. H. ve Wang, E. T. (2006) "Understanding Knowledge Sharing in Virtual Communities: An Integration of Social Capital and
Social Cognitive Theories" Decision Support Systems, 42 (3), 1872-1888.

Cohen, D. (1998) "Towards a Knowledge Context: Report on the First Annual U.C. Berkeley Forum on Knowledge and the Firm" California Management Review, 40 (3), 22-39.

Constant, D., Kiesler, S. ve Sproull, L. (1994) "What's Mine is Ours, or is It? A Study of Attitudes About Information Sharing" Information Systems Research, 5 (4), 400-421.

Cummings, J. N. (2004) "Work Groups, Structural Diversity, and Knowledge Sharing in A Global Organization" Management Science, 50 (3), 352-364.

Cropanzano, R. ve Mitchell, M. S. (2005) "Social Exchange Theory: An Interdisciplinary Review" Journal of Management, 31(6), 874-900.

Çelik, H. E. ve Yılmaz, V. (2013). Yapısal Eşitlik Modellemesi Temel Kavramlar UygulamalarProgramlama. Ankara: Anı Yayıncılık.

Demirel, Y.ve Seçkin, Z. (2008) “Bilgi ve Bigi Paylaşımının Yenilikçilik Üzerine Etkisi”, Ç.Ü. Sosyal Bilimler Enstitüsü Dergisi, 17 (1), 189-202

De Vries, R. E., Van den Hooff, B. ve de Ridder, J. A. (2006) "Explaining Knowledge Sharing the Role of Team Communication Styles, Job Satisfaction, and Performance Beliefs" Communication Research, 33 (2), 115-135.

Fishbein, M. ve Ajzen, I. (1975) Beliefs, Attitude, Intention and Behavior: An Introduction to Theory and Research. Addison-Wesley Pub Lishing Company, Reading, MA.

Fortin, D. R. (2000) “Clipping Coupons in Cyberspace: A Proposed Model of Behavior for Deal-Prone Consumers" Psychology and Marketing, 17, 515-534.

Gray, P. H. (2001) "The Impact of Knowledge Repositories on Power and Control in the Workplace," Information Technology \& People, 14(4), 368-384.

Göksel, A., Aydıntan, B. ve Bingöl, D.(2011)“Örgütlerde Bilgi Paylaşım Davranışı : Sosyal Sermaye Boyutundan Bir Bakış." Ankara Üniversitesi SBF Dergisi, 65 (4), 87109.

Hair, J. F.; Bush, R.P. ve Ortinau, D.J. (2000). Marketing Research A Practical Approach for the New Millenium, 5th Edition, Prentice Hall.

Hall, H. (2001) Social Exchange for Knowledge Exchange," Managing Knowledge: Conversations and 
Critiques. Leicester Üniversitesi Management Centre, Nisan 2011.

Hansen, M.T., (1999) "The Search-Transfer Problem: The Role of Weak Ties in Sharing Knowledge across Organization Subunits, Administrative Science Quarterly, 44, 82-111.

Hendriks, P. (1999) "Why Share knowledge? The Influence of ICT on the Motivation for Knowledge Sharing" Knowledge and Process Management, 6(2), 91-100.

Hsu, M. H., Ju, T. L., Yen, C. H. ve Chang, C. M. (2007) "Knowledge Sharing Behavior in Virtual Communities: The Relationship Between Trust, Self-efficacy, and Outcome Expectations" International Journal of Human-Computer Studies, 65 (2), 153-169.

Husted, K. ve Michailova, S. (2002) "Diagnosing and Fighting Knowledge-Sharing Hostility" Organizational Dynamics, 31 (1), 60-73.

Kankanhalli, A., Tan, B. C. ve Wei, K. K. (2005) "Contributing Knowledge to Electronic Knowledge Repositories: An Empirical Investigation" MIS Quarterly, 113-143.

Köseoğlu, M. A., S. Ocak ve G. Şimşek (2009) "Bilgi Paylaşımını Etkileyen Faktörler Nelerdir?: Bir Kamu Hastanesi Örneği", Uluslararası VII. Bilgi, Ekonomi ve Yönetim Kongresi, Yalova Üniversitesi- İstanbul Üniversitesi, 598-612.

Kubo I., Saka A. ve Pam S. L. (2001) “Behind the Scenes of Knowledge Sharing in a Japanese Bank" Human Resource Development International, 4(4): 465-485.

Kwok, J. S. ve Gao, S. (2004) "Knowledge Sharing Community in P2P Network: A Study of Motivational Perspective" Journal of Knowledge Management, 8(1), 94-102.

Lakhani, K. ve von Hippel, E. (2003) "How Open Source Software Works:'Free'User-to-User Assistance" Research Policy, 32(6), 923-943.

Nonaka, I. (1994) “A Dynamic Theory of Organizational Knowledge Creation", Organization Science, 5 (1). 1437.

Nonaka I., ve Konno, N. (1998) "The Concept of 'Ba': Building a Foundation for Knowledge Creation," California Management Review, 40 (3), 40-54.

O'Dell, C., Grayson, J.C ve Essaides, N. (2003) Ne Bildiğimizi Bir Bilseydik, çev. Günhan Günay. Dışbank Kitapları, Rota, İstanbul.

Polanyi, M. (1966) The Tacit Dimension. Garden City, NY: Anchor Books.
Quinn, J. B., Anderson, P. ve Finkelstein, S. (1996) "Managing Professional Intellect: Making the Most of the Best" Harvard Business Review, 74(2), 71-80.

Ruggles, R. (1998) “The State of the Notion: Knowledge Management in Practice" California Management Review, 40 (3), 80-89.

Ryu, S., Ho, S. H.ve Han, I. (2003) "Knowledge Sharing Behavior of Physicians in Hospitals" Expert Systems with Applications, 25 (1), 113-122.

Swift, M. L. ve Virick, M. (2013) "Perceived Support, Knowledge Tacitness, and Provider Knowledge Sharing" Group \& Organization Management, 38 (6), 717-742.

Sheppard, B. H., Hartwick, J. ve Warshaw, P. R. (1988) "The Theory of Reasoned Action: A Metaanalysis of Past Research with Recommendations for Modifications and Future Research" Journal of Consumer Research, 15 (3), 325-343.

Szulanski, G. (1996) Exploring Internal Stickiness: Impediments to the Transfer of Best Practice within the Firm" Strategic Management Journal, 17, 27-43.

Wang, S. ve Noe, R. A. (2010) "Knowledge Sharing: A Review and Directions for Future Research" Human Resource Management Review, 20 (2), 115-131.

Wasko M. M. ve Faraj, S. (2000) "It is What One Does": Why People Participate and Help Others in Electronic Communities of Practice" The Journal of Strategic Information Systems, 9 (2), 155-173.

Wasko, M. M. ve Faraj, S. (2005) "Why Should I share? Examining Social Capital and Knowledge Contribution in Electronic Networks of Practice" MIS quarterly, 29(1), 35-57.

Von Krogh, G., Ichijo, K. ve Nonaka. I. (2002) Bilginin Üretimi, Çev. Günhan Günay, Dışbank Kitapları. İstanbul: Rota Yayınları.

Yeniçeri, Ö. ve Demirel, Y. (2007) "Örgüt İçi Bilgi Paylaşımına Yönelik Bireysel ve Örgütsel Engeller Üzerine Bir Araştırma", Selçuk Üniversitesi Karaman i.i.B.F. Dergisi, 12, 221-234

Yi, J. (2009) "A Measure of Knowledge Sharing Behavior: Scale Development and Validation" Knowledge Management Research \& Practice, 7(1), 6581.

Zaim, H., Kurt, İ. ve Seçgin, G. (2012). "Örtülü Bilginin Performansa Etkisi: Uluslararsı Bir Banka Uygulaması", Istanbul Ticaret Üniversitesi Sosyal Bilimler Dergisi, 21 (1). 425-442. 